\title{
DEVELOPING A SUSTAINABLE MODEL OF SOCIAL WORK EDUCATION FOR UKRAINE
}

\author{
Nina Hayduk $k^{1}$ and Brad McKenzie ${ }^{2}$
}

\footnotetext{
${ }^{1} \mathrm{MSW}, \mathrm{PhD}$, Associate Professor, Head, Social Work Program, Director of International 'Integration' Centre for Professional Partnerships, Lviv Polytechnic National University

${ }^{2} \mathrm{PhD}$, Professor Emeritus, University of Manitoba, former Director of Reforming Social Services: Canada-Ukraine Project, Doctor Honoris Causa, Lviv Polytechnic National University
}

Background: The four-year Reforming Social Services: Canada-Ukraine Project funded by the Canadian International Development Agency was launched in 1999 with the goal of contributing to civil society reforms in Ukraine through the education of social workers and the strengthening of disability organizations. The project had two components operating under a joint management structure. The Social Work Component involved a partnership between the Faculty of Social Work, University of Manitoba (UM) and Lviv Polytechnic National University (LPNU), and the Disability Component involved a partnership between the Canadian Centre on Disability Studies and a consortium of disability organizations affiliated with the Lviv Independent Living Centre (Faculty of Social Work, 2003).

Purpose: The goal of the Social Work component, which is the focus of this article, was to contribute to civil society reforms in Ukraine by establishing a new, generalist undergraduate social work program at LPNU focused on social work as social change and social justice (International Federation of Social Workers, n.d.).

Methods: A theoretical model based on social development was adopted for the project (Midgley, 1995). One principle associated with the model was to foster opportunities for collective action both in the design and delivery of the social work curriculum and in direct activities to build partnerships with other organizations for social action. This principle was also consistent with the Disability Component's approach to strengthening responses to disability issues both locally and throughout Ukraine. A second principle involved the gradual transfer of full control over program management, including curriculum design and delivery, from the sponsor to the new Department of Sociology and Social Work, LPNU and its community partners in Ukraine during the life of the project. This is reflected in a curriculum that was initially based on the model delivered at the UM with adaptations based on Ukrainian realities to a curriculum that is now fully controlled, and revised as required, by the LPNU Social Work program.

Results: The Social Work program was developed in four stages. The Community Consultation and Strategic Planning stage occurred between 1995 and 1999. During this period a needs assessment study was conducted, and consultation with LPNU, as well as government and non-government organizations, with a special focus on disability organizations, occurred. Support for the development of a social work program focusing on social change and linked to international 
standards was confirmed; as well, evidence emerged that community-based professionals located in agencies also required training in an effort to build their capacity to act as field instruction supervisors for students, and to advance their own knowledge and skills in the new profession of social work.

The Project Implementation stage occurred between 1999 and 2003 during the internationally funded stage of the project. The social work program was established within a new Department of Sociology and Social Work, and a full curriculum for the four-year Bachelor's was designed and implemented. The curriculum was based on the model in place at the UM, with adaptations to better fit the Ukrainian context, as required. During the early implementation stage, most of the social work courses were taught by Canadian instructors with experience in the subject area. Both the curriculum and the teaching methods were highly valued by students. Other accomplishments included advanced social work education and training for five future Ukrainian instructors, the design and delivery of a certificate program in social work for community-based professionals, many of whom later assumed roles as field instruction supervisors for students (Rudy, 2002), and the design and delivery of a course on Innovations in Social Development, which included a special focus on applied research, and the implementation and evaluation of new community-based projects in the human services. Consistent with social development principles, international content was combined with local knowledge and experience on an ongoing basis, and by the fourth-year responsibilities for ongoing teaching and curriculum design was transferred over to the growing number of Ukrainian faculty members employed in the program.

The third stage (from 2003 to 2011) can be described as the Program Consolidation and Sustainability stage. While some teaching and consultation support for curriculum design continued from Canada on a volunteer basis, more local control was assumed by the program, the university and a growing number of community partners that engaged with the LPNU social work program during this period. By the end of this stage, full leadership control of the program was being exercised from Ukraine, and support from Canada and a growing list of partners from other countries was based on specific requests from the local program. A Master's degree program was added and both undergraduate and graduate programs were accredited. The popularity of Social Work with students continued to expand and the national reputation of the social work program grew (Hayduk \& McKenzie, 2012). By 2011, 120 Bachelor's level students were enrolled in the four-year Bachelor's program and there were 56 full and part-time students in the Master's program.

In the Ongoing Innovation and Adaptation stage (2012 to present) new faculty positions have been added, several faculty members have completed advanced post-graduate degrees, and the program now offers a $\mathrm{PhD}$ program. New courses have been added to reflect emerging issues, 
including courses on health and mental health, a sociology program leading to a degree in this discipline, has been established within the Department of Sociology and Social Work, and a new social work specialization on social welfare has been added. A particularly significant development is a new effort to build civil society reforms through the expansion of local, national and international partnerships due to the establishment of the International 'Integration' Centre for Professional Partnerships under the leadership of Dr. Nina Hayduk. Responding to growing needs in the region, a community health clinic model has recently been established at LPNU which integrates student education with the provision of services to the community in collaboration with professional service providers from the community, and research and development opportunities for faculty members within the university. The goal of this innovative outreach initiative is to respond more effectively to needs in three major areas: improved interventions in health and mental health services, more comprehensive services for persons with disabilities, including the promotion of inclusive education, and more responsive services to veterans and their families, including the special needs of those displaced as a result of the conflict in eastern Ukraine. Partnerships at several different levels have been established to promote and implement this model (Hayduk \& Klos, 2019).

Conclusion: Feedback and evaluation results from several sources demonstrate the program's success in educating graduates who are making a difference for individuals, families and communities in Ukraine. Student feedback about the program and performance in national competitions has been very positive, and there is a continuing high demand for entry to the program. There has also been positive feedback from employers and from external examiners who have reviewed the program and the specific performance of students. There has been positive feedback to the role of the program in building partnerships for community social action, and the program is nationally recognized as one of the leading social work programs in the country. The use of a social development model to promote an identity for social work as a profession that provides not only important services to individuals and families but also supports social change for social justice through the transfer of knowledge, the development of local control, and a mission to build partnerships for social action is confirmed.

Keywords: social work and social change, social development, community-based, partnerships, social justice

\section{References}

Faculty of Social Work. (2003). Reforming Social Services: Canada-Ukraine Project final report. Winnipeg: University of Manitoba.

Hayduk, N., \& McKenzie, B. (2012). Developing a sustainable model of social work education in Ukraine. In T. Heinonen \& J. Drolet (Eds.), International social development: Social work experiences andperspectives (pp. 147-169). Halifax \& Winnipeg: Fernwood. 
Hayduk, N., \& Klos, L. (2019). The model of community health clinic of Lviv Polytechnic. Unpublished.

International Federation of Social Workers. (n.d.). Definition of Social Work. Accessed at: $<$ ifsw.org/f38000138.html>

Midgley, J. (1995). Social development. London: Sage.

Rudy, D. (2002). Evaluating professional development training for field instructors in an undergraduate social work program in Ukraine. Master's practicum, Faculty of Social Work, University of Manitoba, Winnipeg.

(C) PSC Proceedings, Italy, 2019 